\title{
MRI based Kidney Radiomics analysis during chronic lithium treatment: validation of a texture index associated with decreased kidney function.
}

Running title: kidney radiomics in lithium-treated patients.

Paul Beunon ${ }^{1,2}$, Maxime Barat ${ }^{2,3}$, Anthony Dohan ${ }^{2,3}$, Lynda Cheddani ${ }^{3,4}$, Lisa Males ${ }^{3,5}$, Pedro Fernandez 5 , Bruno Etain ${ }^{3,6}$, Frank Bellivier ${ }^{3,6}$, François Vrtovsnik ${ }^{3,7}$, Emmanuelle Vidal-Petiot ${ }^{3,8}$, Antoine Khaliil ${ }^{3,5}$, Martin Flamant ${ }^{3,8}$, Nahid Tabibzadeh ${ }^{3,8}$

1. Sorbonne Université

2. Radiologie A, APHP.Centre Hôpital Cochin, Paris, France

3. Université de Paris

4. Unité hypertension artérielle, prévention et thérapeutiques cardiovasculaires, Assistance Publique des Hôpitaux de Paris, Paris, France

5. Radiologie, APHP.Nord Hôpital Bichat, Paris, France

6. AP-HP, Département de Psychiatrie et de Médecine Addictologique, GH LariboisièreFernand-Widal, DMU Neurosciences, Paris, France.

7. Néphrologie, APHP.Nord Hôpital Bichat, Paris, France

8. Explorations Fonctionnelles, Physiologie, APHP.Nord Hôpital Bichat, Paris, France

\section{Corresponding author:}

Nahid Tabibzadeh

Physiologie rénale, explorations fonctionnelles, APHP.Nord Hôpital Bichat, Paris, France Centre de Recherche des Cordeliers, U1138

Université de Paris

nahid.tabibzadeh@inserm.fr

$+331.40 .25 .84 .05$

Keywords: Radiomics - MRI - Chronic Kidney Disease - Lithium - Bipolar disorder 


\section{Abstract}

Background. Chronic lithium therapy is associated with an increased risk of chronic kidney disease (CKD). Lithium nephrotoxicity is slowly progressive and difficult to detect at early stages. The aim of this study was to identify specific image texture changes of kidneys as possible imaging biomarkers of decreased measured glomerular filtration rate (mGFR) using radiomic analysis of $\mathrm{T} 2$ weighted imaging magnetic resonance imaging.

Methods. One hundred and nine patients treated with lithium carbonate were evaluated including mGFR and Kidney MRI, with T2 weighted sequence single-shot fast spin-echo. Computed radiomic analysis was performed after a manual kidney segmentation. Significant features were selected to build a radiomic signature using multivariable Cox analysis to detect a decreased $\mathrm{mGFR}<60 \mathrm{ml} / \mathrm{min} / 1.73 \mathrm{~m}^{2}$. The texture index was internally validated using a training and a validation cohort.

Results. Texture analysis index was able to detect a decrease in mGFR, with an Area Under the Curve (AUC) of 0.85 in the training cohort and 0.71 in the validation cohort. Patients with a texture index below the median were older (59 [42-66] versus 46 [34-54] years, $p=0.001$ ), with longer treatment duration (10 [3-22] versus $6[2-10]$ years, $p=0.02$ ), and a lower mGFR (66 [46-84] versus $\left.83[71-94] \mathrm{ml} / \mathrm{min} / 1.73 \mathrm{~m}^{2}, \mathrm{p}<0.001\right)$. Texture analysis index was independently and negatively associated with age $(\beta=-0.004 \pm 0.001$, $p<0.001)$, serum vasopressin $(-0.005 \pm 0.002, p=0.02)$, lithium treatment duration $(-0.01$ $\pm 0.003, p=0.001$ ), with a significant interaction between lithium treatment duration and mGFR $(p=0.02)$. 
medRxiv preprint doi: https://doi.org/10.1101/2021.10.23.21265420; this version posted October 26, 2021. The copyright holder for this preprint (which was not certified by peer review) is the author/funder, who has granted medRxiv a license to display the preprint in perpetuity. All rights reserved. No reuse allowed without permission.

Conclusion. A renal texture index was developed and validated among patients treated with lithium carbonate associated with a decreased mGFR. This index might be relevant in the diagnosis and prognosis of lithium-induced renal toxicity. 
medRxiv preprint doi: https://doi.org/10.1101/2021.10.23.21265420; this version posted October 26, 2021. The copyright holder for this preprint (which was not certified by peer review) is the author/funder, who has granted medRxiv a license to display the preprint in perpetuity.

\section{Introduction}

Lithium carbonate is the cornerstone long-term treatment of bipolar disorder. The efficacy of lithium is proven in the prevention and treatment of acute maniac and depressive episodes as well as in the prevention of suicidal risk (1-3). However, this efficacy is counterbalanced by potentially serious adverse events. Even at therapeutic ranges, long term lithium treatment might lead to polyuria and polydipsia, related to impaired urine concentrating ability, and eventually to an increased risk of chronic kidney disease (CKD) (4-6).

Specific causal attribution of CKD to lithium treatment in this population is still controversial. Although some authors have related CKD to comorbidities such as ageing, hypertension and metabolic syndrome in these patients (7), late-stage lithiumassociated CKD is characterized by a typical pattern associating tubular atrophy, interstitial fibrosis and diffuse cortical and/or medullary microcysts than can be evidenced on renal magnetic resonance imaging (MRI) (8-11). Moreover, experimental models have shown structural changes early after lithium initiation, characterized by cellular proliferation within renal collecting ducts $(12,13)$. To date, these early changes cannot be detected through non-invasive tests. Yet, the detection of lithium-induced early nephrotoxicity is of major importance when facing the issue of lithium discontinuation and would be help weighing the risk/benefit ratio.

Radiomics is a growing field of research consisting in the mathematical integration of high throughput data produced by medical imaging (14). The image texture is analyzed at the pixel scale, allowing the computation of multiple data. Radiomic analyses have been shown to accurately detect the degree of cancer cell proliferation and heterogeneity within the tissue, hence determining the prognosis of solid tumors (14). It 
might thus represent a noninvasive surrogate biomarker of histological findings, potentially allowing personalized management of patients.

In this view, we hypothesized that non-invasive texture-based imaging biomarkers could provide quantifiable specific modification in patients treated with lithium carbonate and that it could detect a early decrease in measured glomerular filtration rate (GFR) in this population.

We thus aimed at analyzing kidneys of patients treated with lithium using MRI radiomics to internally validate the technique and evaluating the correlates of kidney texture in this population. 


\section{Methods}

\section{Design}

One hundred and fourteen patients on chronic lithium treatment (at least 6 months) with available kidney MRI with T2-weighed coronal sequences were retrospectively included in this monocentric study. Five patients were excluded from the analysis due to artifacts $(n=2)$, inappropriate sequences $(n=1)$, incomplete test $(n=1)$, and solitary kidney $(n=1)$ (study flowchart, figure 1).

\section{Population}

From March 2015 to December 2020, 109 adult patients were referred by psychiatrists to the Department of Renal Physiology for systematic check-up with nephrologists. Eligible patients were $\geq 18$ years of age at inclusion, with various durations of lithium treatment and no dialysis or kidney transplantation history.

All patients provided written informed consent before inclusion in the study cohort. The study was approved by the local ethics committee (Institutional Review Board CER2021-74) and Helsinki's Declaration ethical statements were respected.

\section{Data collection and measurements}

During a half-day in-person visit, clinical and biological parameters were collected. GFR was measured (mGFR) by urinary clearance of ${ }^{99} \mathrm{Tc}$-DTPA or ${ }^{51} \mathrm{Cr}$-EDTA (Curium, Saclay, France and GE Healthcare, Velizy, France respectively) as previously described (15). Plasma lithium concentration was the last available measurement during the last 6 months. Serum vasopressin was measured in the Renal Physiology Laboratory of Hôpital Tenon, France, with a standardized and validated protocol as 
described by Ho et al (16). Desmopressin (dDAVP) was injected 2 hours after the admission of the patient who remained fasting. Maximal urine concentrating ability was defined as the highest value of urine osmolality among the 8 measures performed on urine collected every 30 minutes.

\section{Kidney MRI}

We performed a standardized protocol using T2 weighted sequence single-shot fast spin-echo (SSFSE). T2 SSFSE is an ultrafast MRI technique less susceptible to kinetic or respiratory artifacts and highly T2 weighted sequence allowing an optimal contrast between microcysts and renal parenchyma.

Kidney length was measured pole-to-pole. Cortex thickness was measured in the sagittal plane over the medullary pyramid facing the superior calyx, perpendicular to the cortical surface. Renal microcysts were defined as small (1-2 mm) round cystic lesions and quantified in both kidneys using a semi-quantitative scoring as previously described (8). MRI voxel values were not normalized using the cerebrospinal liquid as all patients were examined on the same machine GE 3T and as voxel value-based features were excluded from the analysis.

Manual segmentation of renal parenchyma excluding sinus, was performed using ITK SNAP 3.8.0. The software package has an interactive viewer that allows visualization in coronal, sagittal and axial planes (Figure 2). Finally, we extracted radiomic features using the pyradiomic module on 3D Slicer software 4.13.0. allowing the extraction of 107 first and second order features $(17,18)$. 


\section{Statistical analyses}

Using a randomization program, the cohort was randomly split into a training cohort $(\mathrm{n}=54)$ and a validation cohort $(\mathrm{n}=55)$. All radiomic features were analyzed and selected using penalized regression Lasso method (19). A Receiver operating characteristic (ROC) Curve was plotted to measure the Area Under the Curve (AUC) and the Youden Index allowed identifying the most accurate cut-off value for the detection of an mGFR below $60 \mathrm{ml} / \mathrm{min} / 1.73 \mathrm{~m}^{2}$. Two first-order features relevant for the prediction of an mGFR below $60 \mathrm{ml} / \mathrm{min} / 1.73 \mathrm{~m}^{2}$ were identified, namely skewness and kurtosis, and the second-order features of the grey level co-occurrence matrix (GLCM) that were identified were correlation and Cluster-Shade. Based on these features we built a quantitative score using fitting generalized linear model, used as a texture analysis index.

Categorical variables were shown as frequencies and percentages, quantitative variables were described as median (quartile 1- quartile 3). Patients' characteristics were shown according to the textile analysis index above or below the median, and compared using the Chi-square test for categorical variables and the Mann-Whitney test for quantitative variables.

Determinants of texture analysis index were assessed using a multivariable linear regression stepwise model. Models were compared by maximum likelihood ratio test (nested models). Validity conditions of the multiple linear regression model were checked. First, the model's suitability was tested using the Rainbow test. We then studied the residuals. Their independence was checked using the Durbin-Watson test 
associated with a graphical method. A quantile-quantile plot was made to check their normal distribution. The distribution's homogeneity has been checked graphically by representating the square root of standardized residuals versus fitted values. The following covariates were included a priori in the model: age, gender, hypertension, lithium treatment duration in years, mGFR, serum vasopressin and the interaction term between lithium treatment duration and mGFR.

A two-sided $p$ value $<0.05$ was considered statistically significant. Statistical analyses and graphs were performed using GraphPad Prism 9.0 and R 3.4 software. 


\section{Results}

Texture analysis index internal validation and accuracy to detect mGFR $<60$ $\mathrm{ml} / \mathrm{min} / 1.73 \mathrm{~m}^{2}$

We built a texture analysis index based on the first and second-order features described above. This quantitative index was tested using an AUC to detect an mGFR $<60$ $\mathrm{ml} / \mathrm{min} / 1.73 \mathrm{~m}^{2}$ (figure 3 ). The AUC was 0.85 in the training cohort and 0.71 in the validation cohort, with a Youden Index at 0.66 in the training cohort and 0.67 in the validation cohort, showing a satisfying internal validation of the technique.

\section{Characteristics of the population}

Characteristics of the studied population are reported in table 1. Median age was 51 [3863] years in the entire cohort, median lithium treatment duration was 7 [2.6-16] years and median mGFR was 77.7 [56.2-90.3] $\mathrm{ml} / \mathrm{min} / 1.73 \mathrm{~m}^{2}$. Compared to patients with a texture analysis index above the median, patients with a texture analysis index below the median were older (46 [34-54] versus 59 [42-66] years, $p=0.001$ ), with a higher body mass index (BMI) (25.5 [22.6-27.4] versus 27 [24.3-29.6] kg/m², $\mathrm{p}=0.01)$, had a longer lithium treatment duration (6 [2-10.3] versus 10 [3.4-22.3] years, $\mathrm{p}=0.02)$, a lower daily lithium dose (800 [720-1200] versus 750 [500-1000] mg/d, $p=0.04)$, a lower maximal urine concentrating ability $\left(701\right.$ [573-856] versus 584 [328-793] $\left.\mathrm{mOsm} / \mathrm{kgH}_{2} \mathrm{O}, \mathrm{p}=0.01\right)$ and more renal microcysts.

Texture analysis index according to patients' characteristics

Texture analysis index was correlated with mGFR and age. The association remained significant between texture analysis index and age in the absence of microcysts 
$\left(r^{2}=0.13, p=0.008\right)$ but not for mGFR (figure $\left.4 A-C\right)$. Regarding the relationship between texture analysis index and lithium treatment duration, the lowest tertile of texture analysis index was observed in the patients with the longest treatment duration (figure 4D). Interestingly, the proportion of texture index within the medium tertile was the highest in patients treated with lithium for less than 5 years compared to longer treatment durations, whereas index within the highest tertile was found in patients treated with lithium for 5 to 15 years.

\section{Determinants of texture analysis index}

Texture index was negatively associated with age $(\beta-0.004 \pm 0.001, p<0.001)$, lithium treatment duration $(-0.01 \pm 0.003, p=0.001)$ and serum vasopressin $(-0.005 \pm 0.002$, $\mathrm{p}=0.02$ ) independently of gender, albuminuria and hypertension (table 2). The association with mGFR vanished when lithium treatment duration was added to the model, but with a significant interaction between treatment duration and mGFR ( $p=0.01)$. 
medRxiv preprint doi: https://doi.org/10.1101/2021.10.23.21265420; this version posted October 26, 2021. The copyright holder for this preprint (which was not certified by peer review) is the author/funder, who has granted medRxiv a license to display the preprint in perpetuity.

All rights reserved. No reuse allowed without permission.

\section{Discussion}

This current study presents the first report of kidney MRI radiomics in patients treated with lithium carbonate. We built a texture analysis index that was associated with a decrease in mGFR. This texture index depended on lithium treatment duration, and was independently associated with age, vasopressin level and mGFR.

Lithium nephrotoxicity remains a major clinical issue because of its slow, asymptomatic and unpredictable evolution, which can lead to end-stage kidney disease (20). The benefit of lithium discontinuation and in particular the reversibility of renal function alteration is currently debated, as well as the probable individual susceptibility $(9,20,21)$. Improved markers are therefore needed in these patients.

In our study, texture features were extracted from MR images and evaluated for their individual performance in detecting a mGFR below $60 \mathrm{ml} / \mathrm{min} / 1.73 \mathrm{~m}^{2}$. The first step was to validate the most relevant variables by means of an internal validation.

In a second step, we established a quantitative index allowing us to put it into the perspective of the patients' characteristics. We observed an association between this index and the duration of lithium exposure. The number of microcysts was also correlated with the texture analysis.

Multivariable analysis of the determinants of this index showed a negative association between texture index and age, independently of lithium treatment duration. One could hypothesize that ageing might modulate kidney texture, raising the potential interest of this marker when studying structural changes associated with renal senescence.

Texture analysis index was also negatively associated with serum vasopressin in our population. Previous research reported the potential adverse effects of vasopressin on CKD progression in various experimental models (22), as well as in polycystic kidney 
medRxiv preprint doi: https://doi.org/10.1101/2021.10.23.21265420; this version posted October 26, 2021. The copyright holder for this preprint (which was not certified by peer review) is the author/funder, who has granted medRxiv a license to display the preprint in perpetuity.

All rights reserved. No reuse allowed without permission.

disease (23). Elevated vasopressin levels in patients treated with lithium salts might reflect renal resistance to the action of vasopressin, eventually leading to decrease urine concentrating ability and nephrogenic diabetes insipidus (4). In line with the pathophysiology of polycystic kidney disease in which vasopressin-dependent V2R signaling induces cellular proliferation and cyst development (24), these findings raise interesting hypotheses regarding the pathophysiology of lithium-associated microcystic tubulo-interstitial nephropathy. Interestingly, previous report from Kline et al. showed that image texture change during PKD predicted CKD progression (25).

Finally, the texture index was negatively associated with lithium treatment duration. Interestingly, the association with mGFR in multivariable analysis disappeared when lithium treatment duration was added to the model. Moreover, a significant interaction was found between lithium treatment duration and mGFR, suggesting that mGFR influences the relationship between kidney texture and lithium exposure. This result should be put in light with our previous report showing an independent and strong relationship between mGFR and lithium treatment duration (8). However, the causative role of each variable is not yet demonstrated. Besides the work from Kline et al. on PKD (25), recent literature has investigated kidney texture analysis in kidney diseases such as glomerulonephritis (26) or radiation-induced kidney damage (27), as well as during CKD $(28,29)$. Berchtold et al. (30) and Friedli et al. (31) have developed an MR imaging tool to detect renal fibrosis using an apparent diffusion coefficient, demonstrating the need for non-invasive diagnostic tools in CKD. To the best of our knowledge, there is no report of the association of histologically proven kidney interstitial fibrosis and radiomics analysis. Further research is thus needed to investigate this association globally during CKD. 
We can identify some limitations to our study. Firstly, our study included a small sample of patients, which nevertheless remains the largest cohort of lithium treated patients with a standardized MRI protocol. Our study also lacks external validation on a control population due to the specific MRI protocol used in these patients. Finally, the crosssectional design of our study does not allow evaluating the prognostic impact of our new biomarker. Our methodological validation with a gold-standard method of GFR measurement might thus be useful to future investigations including longitudinal followup of patients treated with lithium as well as patients with CKD.

In conclusion, we developed and validated a non-invasive renal texture-based imaging index that may be relevant in the diagnosis and prognosis of lithium-induced renal toxicity, as well as ageing and chronic kidney disease. It might also provide insights on pathophysiological mechanisms leading to lithium nephrotoxicity in future studies. 


\section{Disclosures}

The authors declare no conflict of interest.

\section{Funding}

None.

\section{Acknowledgements}

The authors wish to acknowledge the patients who accepted to enter the study, the nursing and medical staff who took care of the patients, and the technical staff who performed the imaging and the radioisotope measurements.

\section{Contributions}

PB, MB, AD and NT designed the study. PB wrote the first draft of the manuscript. PB, LM, PF, EM, FB, BE, EVP, FV, MF and NT collected data. MB, LC and NT analyzed the data. PB conceived figure 1 and 2. MB conceived figure 3. NT conceived figure 4. All the authors contributed to the analyses of the data and edited the manuscript. 


\section{Bibliography}

1. Geddes JR, Burgess S, Hawton K, Jamison K, Goodwin GM. Long-term lithium therapy for bipolar disorder: systematic review and meta-analysis of randomized controlled trials. Am J Psychiatry. 2004 Feb;161(2):217-22.

2. Cipriani A, Hawton K, Stockton S, Geddes JR. Lithium in the prevention of suicide in mood disorders: updated systematic review and meta-analysis. BMJ. 2013 Jun 27;346:f3646.

3. Miura T, Noma H, Furukawa TA, Mitsuyasu H, Tanaka S, Stockton S, et al. Comparative efficacy and tolerability of pharmacological treatments in the maintenance treatment of bipolar disorder: a systematic review and network metaanalysis. Lancet Psychiatry. 2014 Oct;1(5):351-9.

4. Tabibzadeh N, Vrtovsnik F, Serrano F, Vidal-Petiot E, Flamant M. [Chronic metabolic and renal disorders related to lithium salts treatment]. Rev Med Interne. 2019 Sep;40(9):599-608.

5. Shine B, McKnight RF, Leaver L, Geddes JR. Long-term effects of lithium on renal, thyroid, and parathyroid function: a retrospective analysis of laboratory data. Lancet Lond Engl. 2015 Aug 1;386(9992):461-8.

6. McKnight RF, Adida M, Budge K, Stockton S, Goodwin GM, Geddes JR. Lithium toxicity profile: a systematic review and meta-analysis. The Lancet. 2012 Feb 25;379(9817):721-8.

7. Davis J, Desmond M, Berk M. Lithium and nephrotoxicity: a literature review of approaches to clinical management and risk stratification. BMC Nephrol. $2018 \mathrm{Nov}$ 3;19(1):305.

8. Tabibzadeh N, Faucon A-L, Vidal-Petiot E, Serrano F, Males L, Fernandez P, et al. Kidney function and long-term treatment with lithium salts for bipolar disorder Determinants of mGFR and accuracy of kidney microcysts detection in the diagnosis of CKD [Internet]. 2021 Apr [cited 2021 Sep 8] p. 2021.04.11.21255136. Available from: https://www.medrxiv.org/content/10.1101/2021.04.11.21255136v1

9. Markowitz GS, Radhakrishnan J, Kambham N, Valeri AM, Hines WH, D'agati VD. Lithium Nephrotoxicity A Progressive Combined Glomerular and Tubulointerstitial Nephropathy. J Am Soc Nephrol. 2000 Jan 8;11(8):1439-48.

10. Farres MT, Ronco P, Saadoun D, Remy $P$, Vincent F, Khalil A, et al. Chronic lithium nephropathy: MR imaging for diagnosis. Radiology. 2003 Nov;229(2):570-4.

11. Golshayan D, Nseir G, Venetz J-P, Pascual M, Barbey F. MR imaging as a specific diagnostic tool for bilateral microcysts in chronic lithium nephropathy. Kidney Int. 2012 Mar 2;81(6):601. 
12. Christensen BM, Marples D, Kim Y-H, Wang W, Frøkiaer J, Nielsen S. Changes in cellular composition of kidney collecting duct cells in rats with lithium-induced NDI. Am J Physiol Cell Physiol. 2004 Apr;286(4):C952-964.

13. Christensen BM, Kim Y-H, Kwon T-H, Nielsen S. Lithium treatment induces a marked proliferation of primarily principal cells in rat kidney inner medullary collecting duct. Am J Physiol-Ren Physiol. 2006 Jul 1;291(1):F39-48.

14. Lambin P, Leijenaar RTH, Deist TM, Peerlings J, de Jong EEC, van Timmeren J, et al. Radiomics: the bridge between medical imaging and personalized medicine. Nat Rev Clin Oncol. 2017 Dec;14(12):749-62.

15. Vidal-Petiot E, Courbebaisse M, Livrozet M, Corrégé G, Rusu T, Montravers F, et al. Comparison of $51 \mathrm{Cr}-E D T A$ and $99 \mathrm{mTC}-\mathrm{DTPA}$ for glomerular filtration rate measurement. J Nephrol. 2021 Mar 4;

16. Ho TA, Godefroid N, Gruzon D, Haymann J-P, Maréchal C, Wang X, et al. Autosomal dominant polycystic kidney disease is associated with central and nephrogenic defects in osmoregulation. Kidney Int. 2012 Nov;82(10):1121-9.

17. Fedorov A, Beichel R, Kalpathy-Cramer J, Finet J, Fillion-Robin J-C, Pujol S, et al. 3D Slicer as an image computing platform for the Quantitative Imaging Network. Magn Reson Imaging. 2012 Nov;30(9):1323-41.

18. van Griethuysen JJM, Fedorov A, Parmar C, Hosny A, Aucoin N, Narayan V, et al. Computational Radiomics System to Decode the Radiographic Phenotype. Cancer Res. 2017 Nov 1;77(21):e104-7.

19. Tibshirani R. Regression Shrinkage and Selection Via the Lasso. J R Stat Soc Ser B Methodol. 1996;58(1):267-88.

20. Grünfeld J-P, Rossier BC. Lithium nephrotoxicity revisited. Nat Rev Nephrol. 2009 May;5(5):270-6.

21. de Groot T, Ebert LK, Christensen BM, Andralojc K, Cheval L, Doucet A, et al. Identification of Acer2 as a First Susceptibility Gene for Lithium-Induced Nephrogenic Diabetes Insipidus in Mice. J Am Soc Nephrol JASN. 2019 Dec;30(12):2322-36.

22. Bankir L, Bouby N, Ritz E. Vasopressin: a novel target for the prevention and retardation of kidney disease? Nat Rev Nephrol. 2013 Apr;9(4):223-39.

23. Devuyst $O$, Wang $X$, Serra $A$. Vasopressin-2 receptor antagonists in autosomal dominant polycystic kidney disease: from man to mouse and back. Nephrol Dial Transplant. 2011 Aug 1;26(8):2423-5.

24. Yoder BK. Role of primary cilia in the pathogenesis of polycystic kidney disease. $J$ Am Soc Nephrol JASN. 2007 May;18(5):1381-8. 
25. Kline TL, Korfiatis P, Edwards ME, Bae KT, Yu A, Chapman AB, et al. Image texture features predict renal function decline in patients with autosomal dominant polycystic kidney disease. Kidney Int. 2017 Nov;92(5):1206-16.

26. Zhang L, Chen Z, Feng L, Guo L, Liu D, Hai J, et al. Preliminary study on the application of renal ultrasonography radiomics in the classification of glomerulopathy. BMC Med Imaging. 2021 Jul 23;21(1):115.

27. Amiri S, Akbarabadi M, Abdolali F, Nikoofar A, Esfahani AJ, Cheraghi S. Radiomics analysis on CT images for prediction of radiation-induced kidney damage by machine learning models. Comput Biol Med. 2021 Jun;133:104409.

28. Zhang G, Liu Y, Sun $\mathrm{H}, \mathrm{Xu} \mathrm{L}$, Sun J, An J, et al. Texture analysis based on quantitative magnetic resonance imaging to assess kidney function: a preliminary study. Quant Imaging Med Surg. 2021 Apr;11(4):1256-70.

29. Bandara MS, Gurunayaka B, Lakraj G, Pallewatte A, Siribaddana S, Wansapura J. Ultrasound Based Radiomics Features of Chronic Kidney Disease. Acad Radiol. 2021 Feb 12;S1076-6332(21)00012-X.

30. Berchtold L, Crowe LA, Friedli I, Legouis D, Moll S, de Perrot T, et al. Diffusion magnetic resonance imaging detects an increase in interstitial fibrosis earlier than the decline of renal function. Nephrol Dial Transplant. 2020 Jul 1;35(7):1274-6.

31. Friedli I, Crowe LA, Berchtold L, Moll S, Hadaya K, de Perrot T, et al. New Magnetic Resonance Imaging Index for Renal Fibrosis Assessment: A Comparison between Diffusion-Weighted Imaging and T1 Mapping with Histological Validation. Sci Rep. 2016 Jul 21;6(1):30088. 
medRxiv preprint doi: https://doi.org/10.1101/2021.10.23.21265420; this version posted October 26, 2021. The copyright holder for this preprint (which was not certified by peer review) is the author/funder, who has granted medRxiv a license to display the preprint in perpetuity.

\section{Figure and Table Legends}

Table 1: Population characteristics in higher and lower structure index groups. Categorical and continuous data are expressed in $\mathrm{n}(\%)$ and in median [quartile 1quartile 3], respectively. Patients' characteristics were compared across texture analysis index (above or below the median) using the chi-2 test for categorical variables and Mann-Whitney Test for quantitative variables. mGFR: measured glomerular filtration rate, ACR: urinary albumin to creatinine ratio, MRI: magnetic resonance imaging.

Table 2: Multivariable analysis of the determinants of texture analysis index. Determinants were assessed using a multivariable linear regression stepwise model. The following variables were included in the model: age, gender, mGFR, lithium treatment duration, urine albumin/creatinine ratio, hypertension, interaction term between lithium treatment duration and mGFR.

\section{Figure 1: Study Flowchart}

Figure 2: MRI manual renal segmentation on ITK SNAP 3.8 .0

Figure 3: Receiver operating characteristic (ROC) Curve to detect mGFR $<60$ $\mathrm{ml} / \mathrm{min} / 1.73 \mathrm{~m}^{2}$ in the training and the validation cohort

Figure 4: Correlations of texture analysis indexes with patients' characteristics. Texture analysis index according to mGFR (A), to age (B) in patients with no microcysts (blue squares) and in patients with microcysts (red dots). Microcysts quantification according to texture analysis index (C). Texture analysis index tertiles according to lithium treatment duration (D). 
medRxiv preprint doi: https://doi.org/10.1101/2021.10.23.21265420; this version posted October 26, 2021. The copyright holder for this preprint (which was not certified by peer review) is the author/funder, who has granted medRxiv a license to display the preprint in perpetuity.

All rights reserved. No reuse allowed without permission.

Supplemental table: MRI imaging parameters. T2 SSFSE indicates breath-hold T2weighted sequence single-shot fast spin-echo. 
Table 1: Population characteristics in higher and lower structure index groups

\begin{tabular}{|c|c|c|c|c|}
\hline & $\begin{array}{l}\text { overall } \\
\text { population }\end{array}$ & $\begin{array}{l}\text { zmedian structure } \\
\text { index }\end{array}$ & $\begin{array}{l}<\text { median structure } \\
\text { index }\end{array}$ & $p$-value \\
\hline & $\mathrm{n}=108$ & $\mathrm{n}=54$ & $\mathrm{n}=54$ & \\
\hline Age, years & 51 [38-63] & 46 [34-54] & $59[42-66]$ & 0.001 \\
\hline Male & $43(40)$ & $20(37)$ & $23(43)$ & 0.6 \\
\hline $\mathrm{BMI}, \mathrm{kg} / \mathrm{m}^{2}$ & 26 [23-29] & 26 [23-27] & 27 [24-30] & 0.01 \\
\hline Hypertension & $29(27)$ & $13(24)$ & $16(30)$ & 0.5 \\
\hline Diabetes & $3(3)$ & $1(2)$ & $2(4)$ & - \\
\hline Hypothyroidism & $33(31)$ & $15(28)$ & $18(33)$ & 0.5 \\
\hline Lithium treatment duration, years & $7[2.6-16]$ & $6[2-10.3]$ & 10 [3.4-22.3] & 0.02 \\
\hline Sustained-release formulation & $68(63)$ & $34(63)$ & $34(63)$ & 1 \\
\hline Lithium dose, mg/day & $800[600-1000]$ & 800 [720-1200] & $750[500-1000]$ & 0.04 \\
\hline Serum lithium level, $\mathrm{mmol} / \mathrm{l}$ & $0.7[0.6-0.9]$ & $0.7[0.5-0.8]$ & $0.7[0.6-0.9]$ & 0.3 \\
\hline $\mathrm{mGFR}, \mathrm{ml} / \mathrm{min} / 1.73 \mathrm{~m}^{2}$ & $78[56-90]$ & $83[71-94]$ & $66[46-84]$ & $<0.001$ \\
\hline $\mathrm{ACR}, \mathrm{mg} / \mathrm{mmol}$ & $1.4[0.9-2.6]$ & $1.4[0.9-2.3]$ & $1.5[0.9-2.6]$ & 0.7 \\
\hline Urine output, I/day & $2.3[1.7-3.2]$ & 2.4 [1.9-3.2] & $2.3[1.6-3.5]$ & 0.5 \\
\hline $\begin{array}{l}\text { Maximal urinary osmolality, } \\
\mathrm{mOsm} / \mathrm{kgH}_{2} \mathrm{O}\end{array}$ & 665 [480-839] & $701[573-856]$ & 584 [328-793] & 0.01 \\
\hline Serum vasopressin, $\mathrm{pg} / \mathrm{ml}$ & $6.6[4.4-12.3]$ & $5.7[4.0-10.0]$ & $7.9[4.6-13.4]$ & 0.08 \\
\hline \multicolumn{5}{|l|}{ Kidney MRI } \\
\hline Number of cysts & $0[0-0]$ & $0[0-0]$ & 0 [0-2] & - \\
\hline Number of microcysts & & & & 0.002 \\
\hline 0 & $53(49)$ & $36(67)$ & $17(31)$ & \\
\hline $1-5$ & $25(23)$ & $9(17)$ & $16(30)$ & \\
\hline $6-10$ & $6(6)$ & $2(4)$ & $4(7)$ & \\
\hline $11-20$ & $6(6)$ & $3(6)$ & $3(6)$ & \\
\hline $21-50$ & $6(6)$ & $5(9)$ & $4(7)$ & \\
\hline $51-100$ & $3(3)$ & $1(2)$ & $2(4)$ & \\
\hline$>100$ & $9(8)$ & $1(2)$ & $8(15)$ & \\
\hline Structure analysis index & $0.79[0.66-0.86]$ & $0.86[0.82-0.90]$ & $0.66[0.48-0.74]$ & $<0.001$ \\
\hline
\end{tabular}

Categorical and continuous data are expressed in $\mathrm{n}(\%)$ and in median [quartile 1- quartile 3], respectively. Patients' characteristics were compared across texture analysis index (above or below the median) using the chi-2 test for categorical variables and Mann-Whitney for quantitative variables. mGFR: measured glomerular filtration rate, ACR: urinary albumin to creatinine ratio, MRI: magnetic resonance imaging. 
medRxiv preprint doi: https://doi.org/10.1101/2021.10.23.21265420; this version posted October 26, 2021. The copyright holder for this preprint (which was not certified by peer review) is the author/funder, who has granted medRxiv a license to display the preprint in perpetuity.

All rights reserved. No reuse allowed without permission.

Table 2. Multivariable analysis of the determinants of texture analysis index.

\begin{tabular}{|llr|}
\hline Dependent variable: texture index & $\boldsymbol{\beta} \pm \mathrm{SE}$ & $\boldsymbol{p}$ value \\
\hline age & $-0.004 \pm 0.001$ & $\mathbf{0 . 0 0 1}$ \\
\hline Lithium treatment duration & $-0.01 \pm 0.003$ & $\mathbf{0 . 0 0 1}$ \\
\hline mGFR & $-0.0008 \pm 0.003$ & 0.5 \\
\hline Serum vasopressin & $-0.005 \pm 0.002$ & $\mathbf{0 . 0 2}$ \\
\hline mGFR ${ }^{\star}$ treatment duration interaction & - & $\mathbf{0 . 0 1}$ \\
\hline
\end{tabular}

Determinants were assessed using a multivariable linear regression stepwise model. The following variables were included in the model: age, gender, mGFR, lithium treatment duration, urine albumin/creatinine ratio, hypertension, interaction term between lithium treatment duration and mGFR. 
Figure 1. Study Flowchart

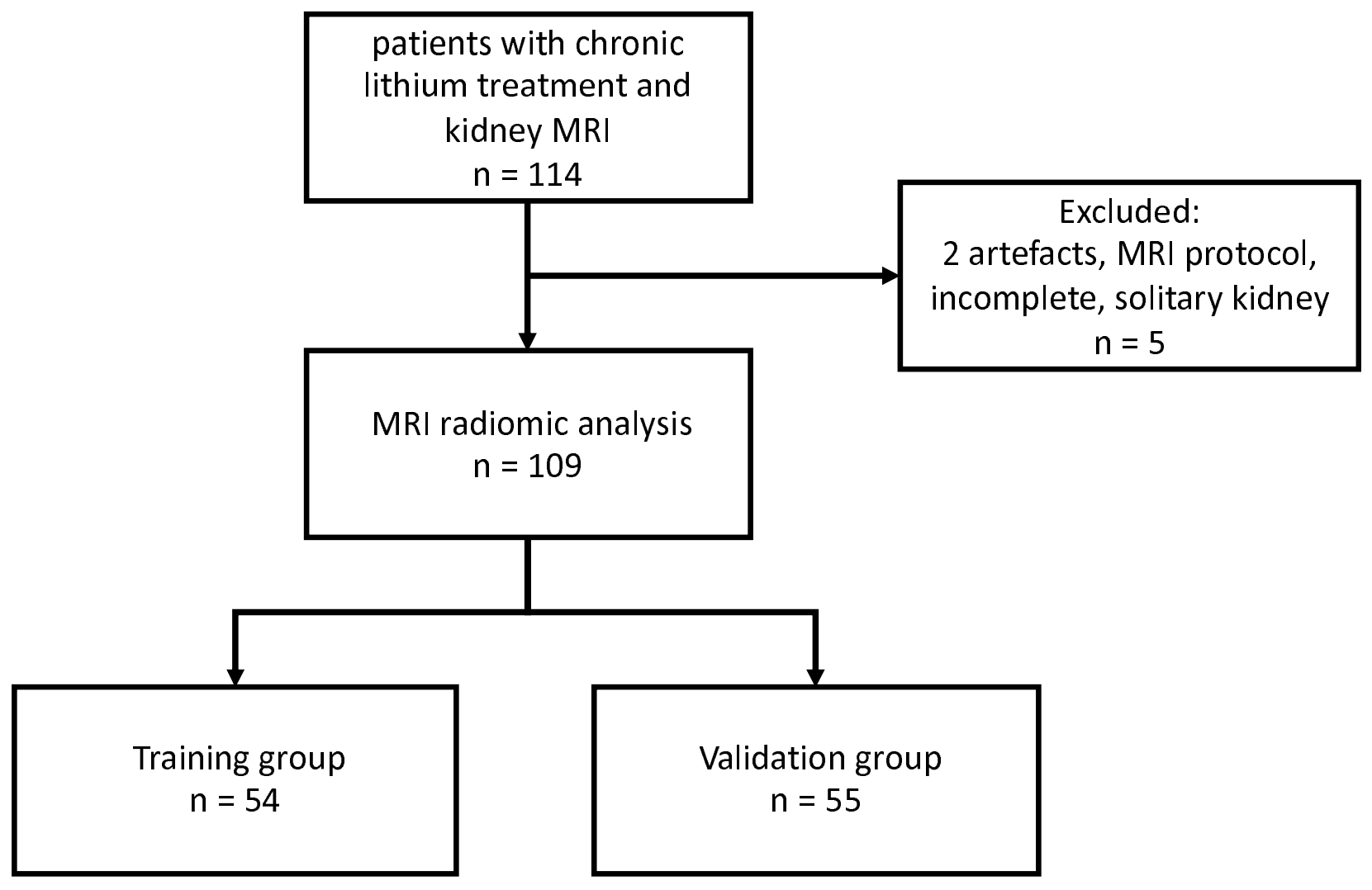


medRxiv preprint doi: https://doi.org/10.1101/2021.10.23.21265420; this version posted October 26, 2021. The copyright holder for this preprint

(which was not certified by peer review) is the author/funder, who has granted medRxiv a license to display the preprint in perpetuity.

All rights reserved. No reuse allowed without permission.

\section{Figure 2: MRI manual renal segmentation on ITK SNAP 3.8.0}
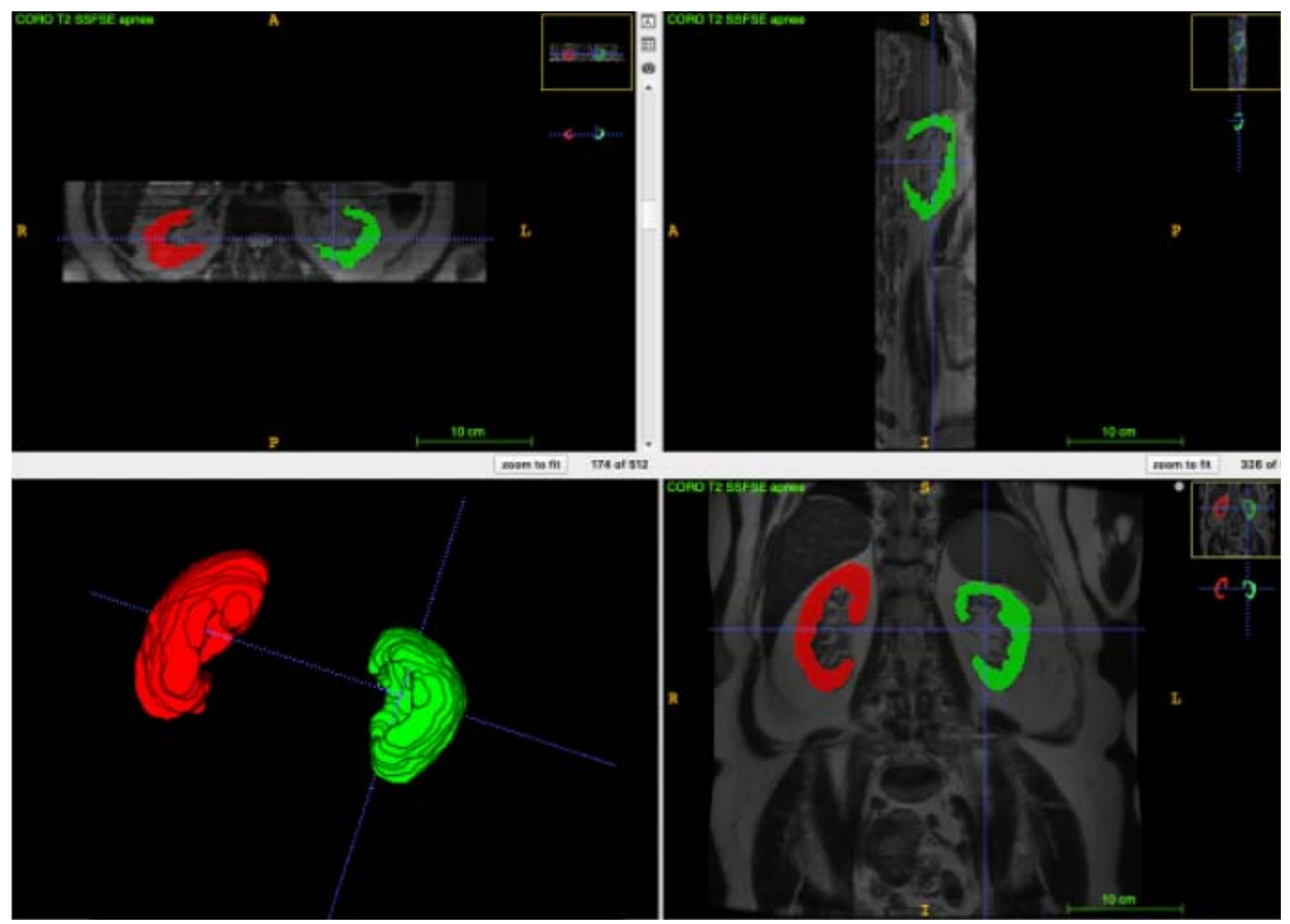
Figure 3: Receiver operating characteristic (ROC) Curve to detect mGFR $<60$ $\mathrm{ml} / \mathrm{min} / 1.73 \mathrm{~m}^{2}$ in the training and the validation cohort

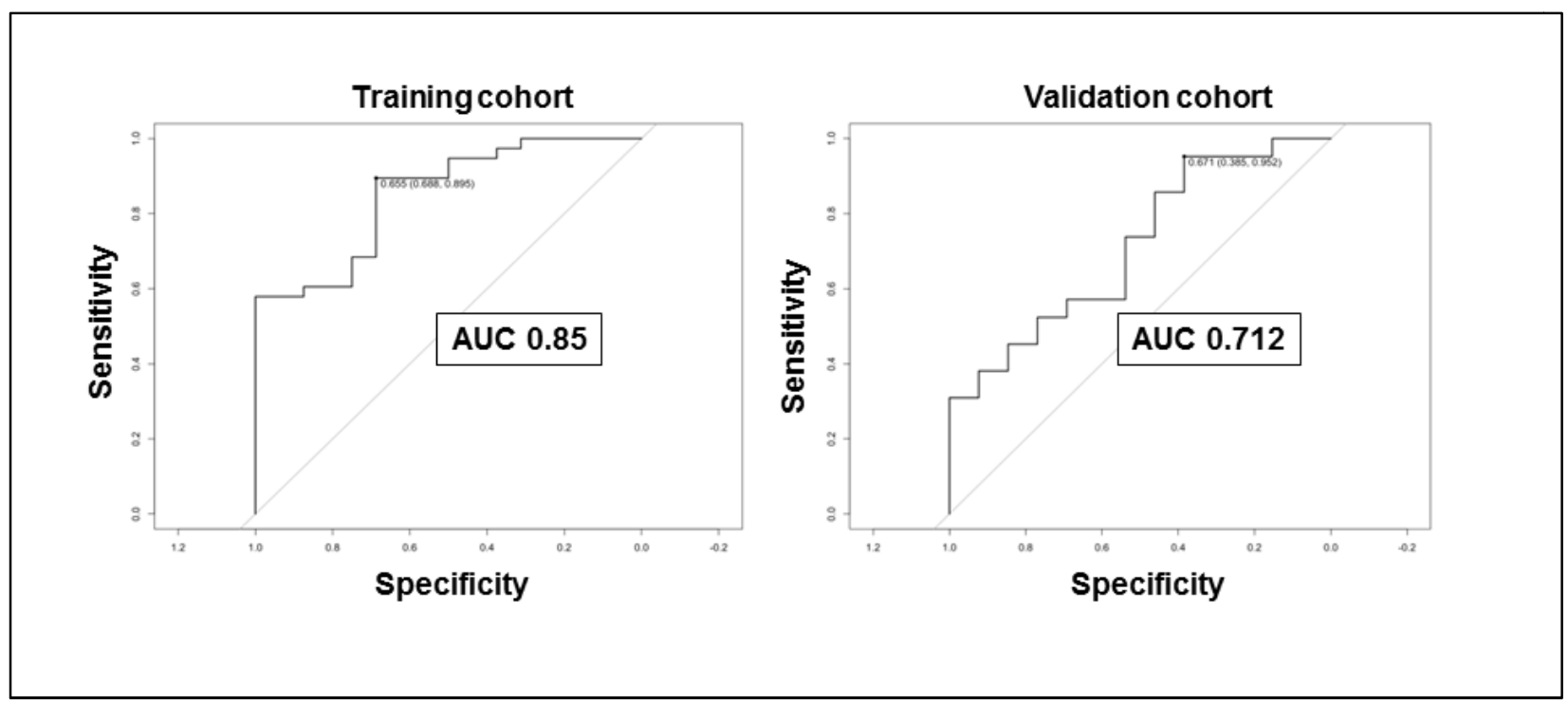


Figure 4: Correlations of texture analysis indexes with patients characteristics.

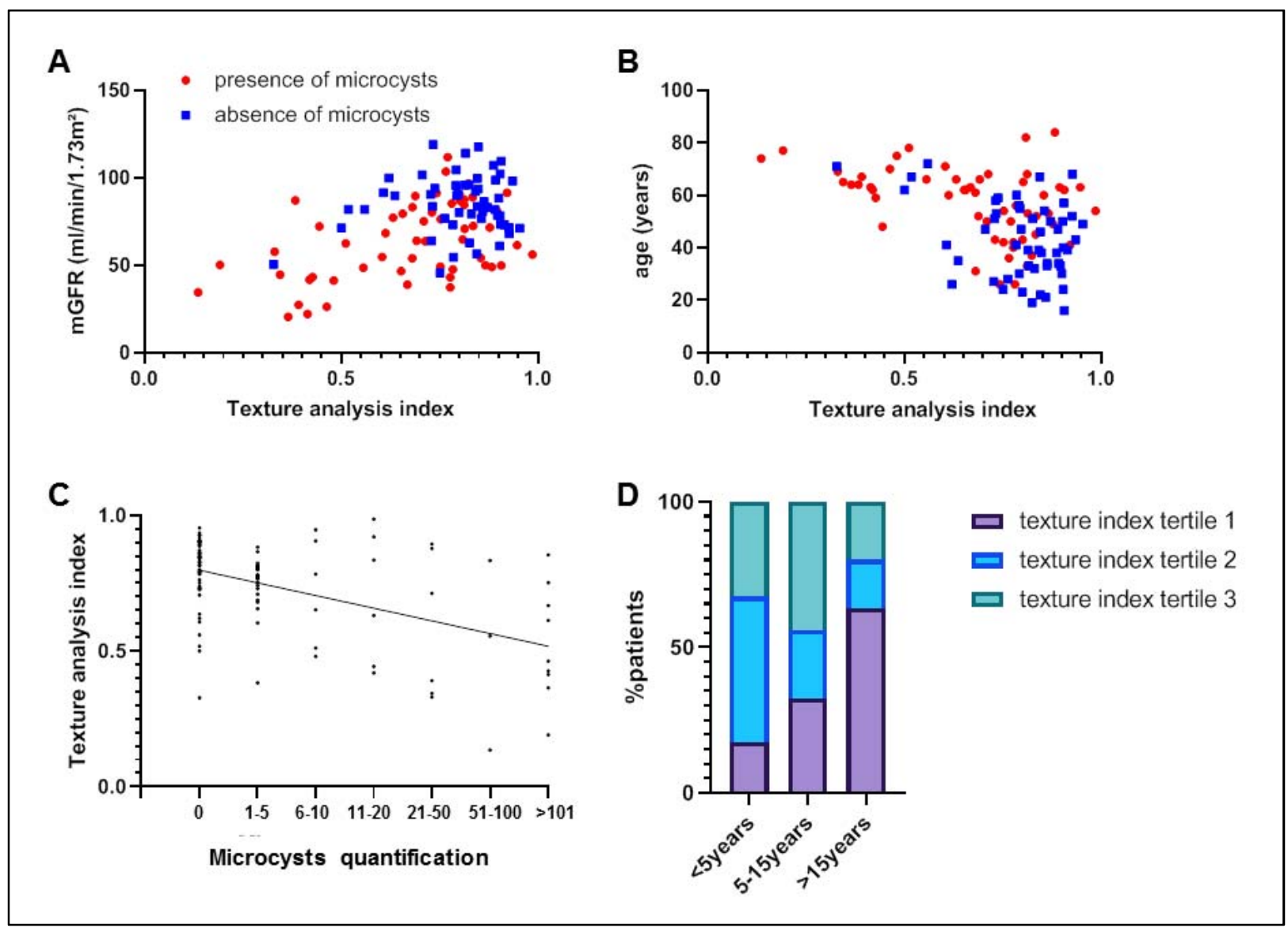

Texture analysis index according to mGFR (A), to age (B) in patients with no microcysts (blue squares) and in patients with microcysts (red dots). Microcysts quantification according to texture analysis index (C). Texture analysis index tertiles according to lithium treatment duration (D). 
medRxiv preprint doi: https://doi.org/10.1101/2021.10.23.21265420; this version posted October 26, 2021. The copyright holder for this preprint

(which was not certified by peer review) is the author/funder, who has granted medRxiv a license to display the preprint in perpetuity.

All rights reserved. No reuse allowed without permission.

\section{Supplemental table. MR Imaging parameters}

\begin{tabular}{|l|l|}
\hline & T2 SSFSE \\
\hline Plane & Coronal \\
\hline Repetition time $(\mathrm{ms})$ & $1700-1850$ \\
\hline Echo time $(\mathrm{ms})$ & $85-95$ \\
\hline Flip angle $\left(^{\circ}\right)$ & 90 \\
\hline Fat suppression & No \\
\hline Slice thickness (mm) & 3 \\
\hline Intersection gap (mm) & 0 \\
\hline Number of slices & $27-33$ \\
\hline Matrix size & $512 \times 320$ \\
\hline Number of signal averages & 1 \\
\hline Acquisition time (sec) & $145-160$ \\
\hline
\end{tabular}

T2 SSFSE indicates breath-hold T2-weighted sequence single-shot fast spin-echo. 